\title{
Localization of deformed wing virus (DWV) in the brains of the honeybee, Apis mellifera Linnaeus Karan S Shah ${ }^{1}$, Elizabeth C Evans ${ }^{1,2}$ and Marie C Pizzorno*1,3
}

\author{
Address: ${ }^{1}$ Department of Biology, Bucknell University, Lewisburg, PA 17837, USA, ${ }^{2}$ Animal Behavior Program, Bucknell University, Lewisburg, PA \\ 17837, USA and ${ }^{3}$ Cell Biology and Biochemistry Program, Bucknell University, Lewisburg, PA 17837, USA \\ Email: Karan S Shah - karan.shah@bucknell.edu; Elizabeth C Evans - elizabeth.capaldi@bucknell.edu; \\ Marie C Pizzorno* - pizzorno@bucknell.edu \\ * Corresponding author
}

Published: 30 October 2009

Virology Journal 2009, 6:182 doi:10.1186/1743-422X-6-182

This article is available from: http://www.virologyj.com/content/6/I/182

(C) 2009 Shah et al; licensee BioMed Central Ltd.

This is an Open Access article distributed under the terms of the Creative Commons Attribution License (http://creativecommons.org/licenses/by/2.0), which permits unrestricted use, distribution, and reproduction in any medium, provided the original work is properly cited.
Received: II June 2009
Accepted: 30 October 2009

\begin{abstract}
Background: Deformed wing virus (DWV) is a positive-strand RNA virus that infects European honeybees (Apis mellifera L.) and has been isolated from the brains of aggressive bees in Japan. DWV is known to be transmitted both vertically and horizontally between bees in a colony and can lead to both symptomatic and asymptomatic infections in bees. In environmentally stressful conditions, DWV can contribute to the demise of a honeybee colony. The purpose of the current study is to identify regions within the brains of honeybees where DWV replicates using in-situ hybridization.
\end{abstract}

Results: In-situ hybridizations were conducted with both sense and antisense probes on the brains of honeybees that were positive for DWV as measured by real-time RT-PCR. The visual neuropils demonstrated detectable levels of the DWV positive-strand genome. The mushroom bodies and antenna lobe neuropils also showed the presence of the viral genome. Weaker staining with the sense probe in the same regions demonstrates that the antigenome is also present and that the virus is actively replicating in these regions of the brain.

Conclusion: These results demonstrate that in bees infected with DWV the virus is replicating in critical regions of the brain, including the neuropils responsible for vision and olfaction. Therefore DWV infection of the brain could adversely affect critical sensory functions and alter normal bee behavior.

\section{Background}

European honeybees (Apis mellifera L.) play a crucial role in agricultural industries by pollinating crops $[1,2]$. Unlike other pollinators, these bees are generalist foragers that readily visit multiple types of plants; they serve as an alternative to the species-specific pollinators [3]. In addition, honeybees are flower-constant, meaning that they usually restrict their visits to flowers of the same species during foraging flights and bypass valuable, alternative food sources [4]. This behavioral trait is thought to increase pollination efficiency of these pollinators compared to others.

There have been at least 16 viruses, primarily of the picorna-like group of positive-strand RNA viruses, known to infect honeybees [5]. One commonly detected honeybee virus is the deformed wing virus (DWV), which belongs to the Iflavirus genus, a group of viruses distantly related to human picornaviruses, like polio and rhinovirus $[6,7]$. DWV was first isolated from honeybees in the 
1980s in Japan and is now found in all parts of the world where Varroa mites are found $[5,8,9]$. Varroa destructor is a mite that parasitizes immature and adult bees by feeding on them and has the ability to serve as a vector to transmit the virus horizontally [10-13]. A high density of mites in a colony suppresses the immune function of the bees by reducing the transcription of antimicrobial peptides and immune related enzymes $[14,15]$. The reduced levels of these immune related enzymes appears to exacerbate DWV infection and can lead to the demise of the colony [15].

Even in the absence of the mites, DWV can be transmitted vertically through infected eggs and sperm [16-18]. Typical symptoms exhibited by severely infected bees are crumpled wings, bloated abdomens, paralysis, learning deficits, and a drastically shortened life span and there is a direct correlation between the viral titer and the symptoms displayed [10]. Symptoms of the viral infection are most prevalent during stressful environmental conditions, leading to reduced performance in infected colonies [19-21]. Therefore as the number of infected worker bees increases, the colony is less likely to survive.

DWV is a positive-strand RNA virus that produces a 30$\mathrm{nm}$ icosahedral particle composed of three major structural proteins [6]. As a member of the Iflavirus genus, DWV has a typical picornavirus genome organization consisting of a single open reading frame flanked by $1144 \mathrm{nt}$ $5^{\prime}$ and $317 \mathrm{nt} 3^{\prime}$ nontranslated regions, which contain putative replication and translational control elements $[6,22]$. The viral RNA is presumed to be polyadenylated and the structural proteins are $\mathrm{N}$-terminal to the nonstructural proteins [6]. DWV genome sequences are highly conserved in most parts of the world [9] and have a very close sequence homology to two other iflaviruses Kakugo virus (KV) and Varroa destructor virus 1 (VDV-1) $[6,23,24]$. Currently there is disagreement on whether DWV and KV are actually regional isolates of the same virus [6] or two separate species [24]. KV was first isolated from aggressive bees in Japan; however, there has been no direct correlation made between the aggressiveness of the bees and the presence of KV or DWV [25]. Specific molec- ular techniques have been developed to sensitively detect both DWV and KV genomes $[6,23,26]$, however the high sequence homology between the two viruses makes it difficult to differentiate between them. While it has also been shown that DWV infection impairs associative learning [27], it has not been shown to increase aggression as has been proposed for KV [25].

In this study, we identified the presence and replication of DWV viral RNA in several areas of the brains of infected honeybees. The data presented here show that DWV localizes in the olfactory and visual regions, which may alter the normal behavior of the bees and contribute to the demise of the colony.

\section{Results \\ Real Time PCR Results}

Real-time RT-PCR was used to quantify DWV viral RNA and to identify bees that carried relatively high viral loads (Table 1). This procedure was carried out on bees collected from two different hives to determine the level of DWV RNA in the bees that were used in the in situ hybridizations. Real-time RT-PCR confirmed that bees can show highly variable levels of DWV RNA, whether they are morphologically symptomatic or not for DWV infection (Table 1). The level of DWV RNA also increases in bees collected later in the season when the bees are more likely to be symptomatic. This could be due to higher levels of mite infestation later in the season or harsher environmental conditions and reduced food sources [21]. Realtime PCR data suggest that many, but not all, of the bees in Hive D carry at least low levels of DWV RNA (data not shown). Interestingly, some asymptomatic bees had very high levels of viral RNA and the brains from these bees showed a strong hybridization with the virus probes.

\section{In-situ Hybridization Results}

We conducted in-situ hybridizations to detect the presence and localization of DWV RNA in bee brains. The positive-strand viral RNA was present in the visual neuropils, including the crescent shaped medulla, as shown from the staining pattern observed with the antisense probe (Figure $1 \mathrm{~A}, \mathrm{~B}$ and $1 \mathrm{D})$. The staining is localized in a punctate pat-

Table I: Number of copies of the DWV genome in tested bees using real-time RT-PCR.

\begin{tabular}{ccccc}
\hline Bee Number & Hive & Date Sampled & Symptomatic & DWV copies/ $\mu$ total RNA \\
I & B & July 2007 & - & $10^{3}$ \\
2 & D & July 2007 & - & $5 \times 10^{5}$ \\
3 & D & July 2007 & - & $6 \times 10^{6}$ \\
4 & D & Sept. 2007 & - & $4 \times 10^{7}$ \\
5 & D & Sept. 2007 & + & $5 \times 10^{7}$
\end{tabular}

The number of copies of viral RNA per $\mu \mathrm{g}$ of total bee RNA was calculated for the honeybees shown in Figures I and 2 using real-time RT-PCR. The copy number was calculated from a standard curve of a plasmid containing the DWV amplicon. Actin was used as an internal control and the $\mathrm{Ct}$ numbers were within 2.0 from each other. 


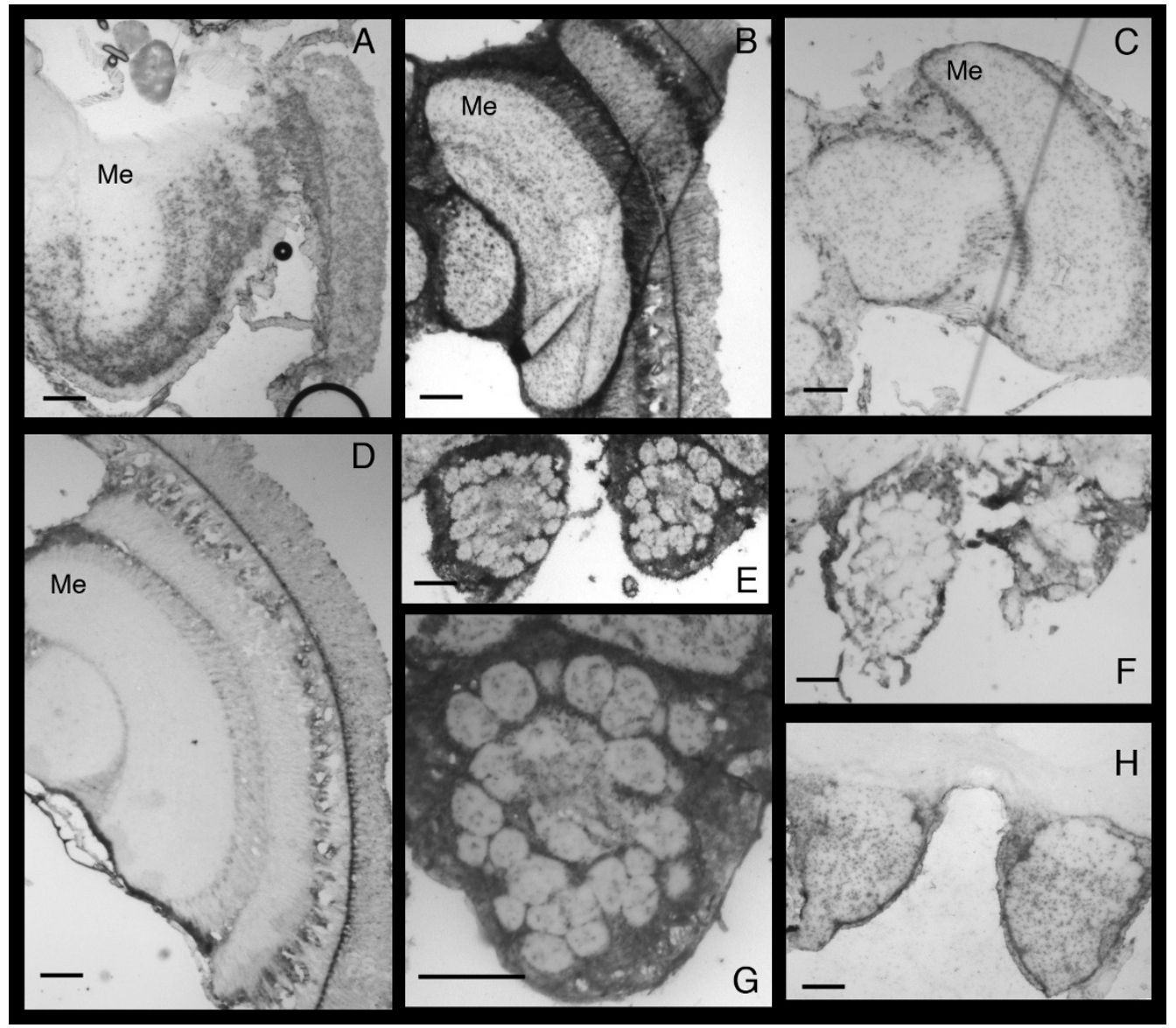

Figure I

Detection of the genome and antigenome of DWV in the optic lobe, the antenna lobe and the subesophageal ganglion of honeybee brains. In-situ hybridization of DWV positive bee brains with antisense probes $(A, B, D, E, G, H)$ and sense probes (C, F). A, optic lobe from bee\#3 with antisense probe, 4×; B, optic lobe from bee\#5 with antisense probe, $4 \times$; $C$, optic lobe from bee\#3 with sense probe, $4 \times$; D, optic lobe from bee\#2 with antisense probe, 4×; E, antenna lobe from bee \#5 with antisense probe, $4 \times ; F$, antenna lobe from bee \#5 with sense probe, 4×; G, magnification of E, I0x; H, subesophageal ganglion from bee \#3 with antisense probe, $4 \times$; bar $=100 \mu \mathrm{m}$. The notation Me in panels A, B, C, and D identifies the crescent shaped medulla region of the brain.

tern throughout the medulla region of the optic lobe of the bee brain (Me, Figure 1). Two of the in-situ hybridizations (Figure 1A and 1D) were conducted on bees collected from hive D early in the summer, which showed moderate levels of the viral RNA as measured by real time PCR (Table 1) while the darker staining sections (Figure $1 \mathrm{~B}, \mathrm{E}, \mathrm{G})$ were taken from Bee \#5 with higher levels of viral RNA (Table 1). To determine whether the virus is actively replicating, a second section from Bee\#3 was hybridized to the sense probe (Figure 1C). The detection of the antigenome by the sense probe, while lighter staining, confirms replication of the virus in this region of the brain. The viral genome was also detected in the subesophageal ganglion found near the back of brain (Figure $1 \mathrm{H}$ ). An additional in-situ hybridization was conducted on Bee\#5 to determine if the virus infects and rep- licates within the antenna lobes of the brain. These results showed both viral RNA and antigenome in antenna lobes (Figure 1E-G), which are responsible for receiving and processing olfactory signals from the antenna.

Finally, because the corpora pedunculata neuropil (mushroom bodies) of insect brains is crucial for the detection and integration of external stimuli, we conducted in-situ hybridizations to determine if the virus is present in this region. In both asymptomatic Bee\#2 and symptomatic Bee \#6, which carries a very high level of viral RNA (Table 1 ), the mushrooms bodies contain viral RNA (Figure 2A and $2 \mathrm{~B}$ ). The differences in the staining pattern between the sections taken from these two bees is likely due to the differences in the level of viral RNA they carried (Table 1). In addition, Bee\# 6 shows the presence of the antigenomic 


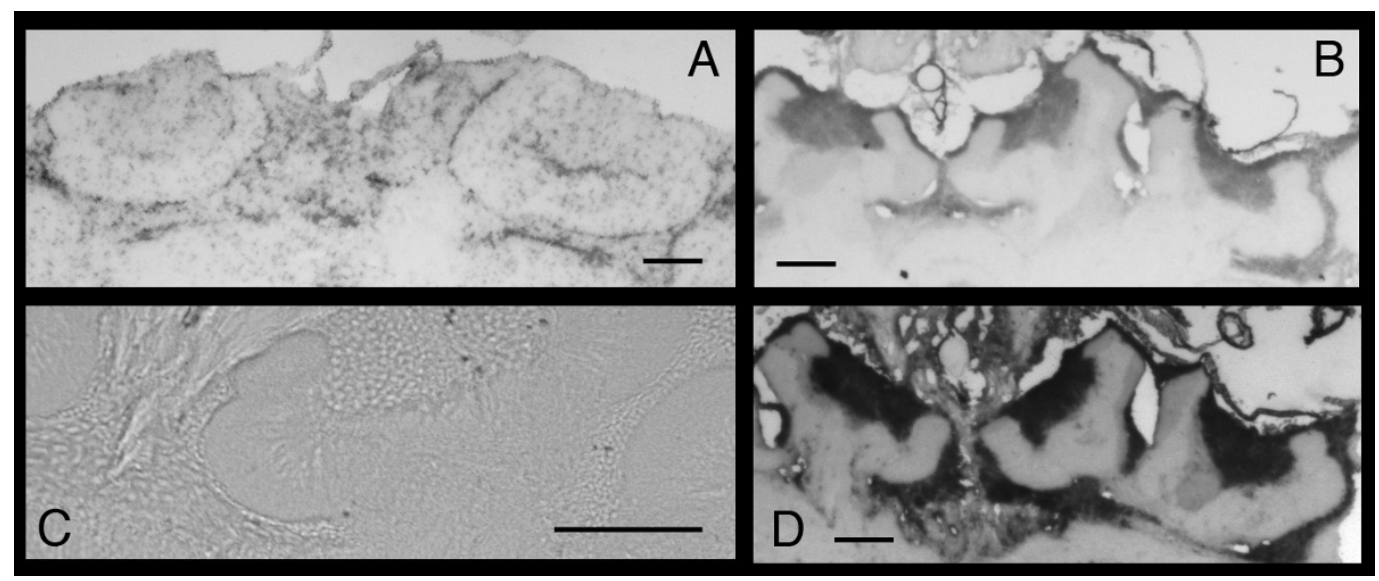

\section{Figure 2}

Detection of the genome and antigenome of DWV in the mushroom bodies of honeybee brains. In situ hybridization of mushroom bodies from DWV positive (A, B, D) and DWV negative (C) bee brains. A, bee \#4 with antisense probe, 4×; $B$, bee \#6 with sense probe, 4×, C, bee\#I with antisense probe, 4×; D, bee \#6 with antisense probe, $10 \times$; bar = $100 \mu \mathrm{m}$.

RNA (Figure 2D). Finally, our antisense probe does not hybridize to brain sections from Bee\# 1 with very low levels of viral RNA (Figure 2C), as measured by real-time RTPCR (Table 1). This finding demonstrates that the hybridization is specific and the probe does not detect any cellular RNA.

\section{Discussion}

DWV is a positive-strand RNA virus that has a $97 \%$ sequence homology with KV [6]. Because KV was first identified in attacker bees in Japan, there has been some interest in determining if $\mathrm{DWV} / \mathrm{KV}$ can cause aggressive behavior in the honeybee. Some reports do not correlate virus infection with aggression [25], while other reports suggest that they may be a link between virus infection and either aggression or learning deficits in bees $[23,24,27]$. Because of this link between DWV/KV infection and changes in bee behavior, we sought to determine which regions of the honeybee brain are infected with DWV/KV using in-situ hybridization.

The in-situ hybridizations results demonstrate that the DWV genomic RNA was present in high concentrations in the optic and antennal neuropils in the bee brain and in mushroom bodies. We can therefore conclude that the virus is present in the brain regions that process the bees' sensory experiences. In addition, brain sections that were hybridized to the sense probe also showed lighter staining in these same regions. This discovery demonstrates the presence of the antigenomic viral RNA and that the virus is actively replicating in these areas of infected bee brains. The lighter staining with the sense probe is expected since picorna-like viruses produce only $10 \%$ as much of the antigenomic RNA to act as the template strand for the rep- licating viral genomes [28]. Finally, we note that most of the viral RNA appears to be detected in a punctate pattern, which may be the cell bodies of the neurons. This finding is consistent with the known subcellular location for replication of other picornaviruses, such as polio [29]. However, we can not rule out that the punctate staining represent viral RNA replication in other cells, such as glial cells. Further staining with neuronal and glial cell markers will be needed to answer this question.

The presence of replicating virus in the optic neuropils may indicate that infected bees have impaired vision. A similar conclusion can be drawn from the evidence of high viral load in the antennal lobes: this infected neural tissue could indicate a deficit in olfactory processing. Therefore, it is possible that the virus affects the bees' flight behavior, homing performance, and perception of odorants. While future experiments will undoubtedly reveal the nature of the behavioral impairment attributable to DWV, it is at least plausible that this viral infection contributes to the bee disappearances associated with colony collapse disorder [30,31]. Recent work by Johnson et al [30] suggests that viral infections, most likely DWV since it is a common infection in many US hives, might lead to the fragmentation of rRNA within cells, affecting cellular metabolic function and leading to CCD.

It should be noted that a previous report detected the viral genome in other tissues, including the reproductive organs, in both queen and drone bees [32], but failed to detect viral RNA in the brain. We propose that the explanation for this discrepancy is that our methods, which included the use of a longer riboprobe and cryosections, produced a higher sensitivity. We also studied worker bees 
rather than queens or drones, which could also explain the differences in our results.

\section{Conclusion}

We have detected both DWV genomic and antigenomic viral RNA in the brains of infected worker honeybees using in-situ hybridization. This demonstrates that DWV is not only present in the brains of bees, but is also actively replicating. Because the regions infected include those involved in sight and olfaction we predict that DWV infected bees will have difficulty with their vision or sense of smell; if either system is impaired, their ability to function normally as a productive member of the hive would be compromised.

\section{Methods \\ Isolation of viral RNA from bees/cDNA synthesis Collection of Bees}

Bees were collected from the hives located in Bucknell's apiary. One of the hives, Hive D, was obtained from D. Cox-Foster, Penn State University. Bees, most likely foragers, were chosen at random upon their departure from the hive and killed by freezing at $-80^{\circ} \mathrm{C}$ Celsius. For later experiments, both asymptomatic bees and young or newly emerged bees with crumpled wings were chosen from Hive D, which was known to be positive for DWV.

\section{RNA Isolation}

RNA was isolated from the abdomen and thoraxes of adult bees, whole pupae, and larvae using Trizol (Invitrogen). The bee tissues were homogenized in $800 \mu \mathrm{l}$ of Trizol and extracted using $200 \mu \mathrm{l}$ of chloroform. The RNA was precipitated from the aqueous fraction with $400 \mu \mathrm{l}$ of isopropyl alcohol. The RNA pellet was washed with $75 \%$ ethanol, air dried, and then re-suspended in DEPC treated sterile water. The quality and quantity of the isolated RNA was measured using a Nanodrop spectrophotometer.

\section{CDNA synthesis}

In order to synthesize cDNA, 2 ug of total isolated RNA was combined with random decamers according to the procedure from RETROscript cDNA synthesis kit (Ambion).

\section{Standard RT-PCR and Cloning}

\section{$P C R$ Primer Sequences and Condition}

In order to clone the region of the DWV genome between nucleotide 8371 and 8748 to use as a probe for in-situ hybridizations, the following primer sequences were used: DWV1-F (5'-GGACTGAACCAAATCCGATGTCATCACG-3') and DWV1-R (5'-TCTCAAGTTCGGGACGCATTC-3'). PCR was conducted using Failsafe PCR kit (Epicentre) and contained $1 \mu \mathrm{l}$ cDNA, $1 \mu \mathrm{M}$ of forward and reverse primers, $0.5 \mu \mathrm{l}$ of Failsafe PCR polymerase mix and $25 \mu$ lof the appropriate $2 \times$ PCR buffer.

\section{PCR Product Cloning}

The 378 bp PCR product was cloned into the pCR2.1 dual promoter vector using the TA cloning kit (Invitrogen) according to manufacturer's instructions. DNA sequencing was used to confirm the identity of the cloned insert. Two plasmids were used, each containing the PCR insert in opposite directions in relation to the $\mathrm{T} 7$ promoter. When transcribed using the T7 RNA polymerase, the pDWV-F produces RNA that is sense to the viral genome while the plasmid named pDWV-R produces RNA that is antisense to the DWV viral genome.

\section{Real-Time PCR}

RT-PCR

Real Time RT-PCR was used to quantify the amount DWV RNA. Two primer sets were used to measure cellular and viral RNA (actin or DWV). Primers were designed using the Primer3 program and the specificity was confirmed using the BLAST program (NCBI). The primer sequence for actin left was (5'-GACGAGTCTGGACCATCCAT-3'), and the primer sequence for actin right was (5'-GGGATTCGGGGAATGAGTAT- 3 '). The DWV left primer sequence was (5'-AGCATGGGTGAAGAAATGTC-3'), and the DWV right primer sequence was (5'-ATATGAATGTGCCGCAAACA-3'), which amplifies the region between base 5288 and 5390 on the DWV genome. Each real-time PCR reaction contained $12.5 \mu \mathrm{l}$ of $2 \times$ SYBR super mix (BioRad), $1 \mu$ l of a 1:5 dilution of cDNA, and forward and reverse primers at a final concentration of $0.1 \mu \mathrm{M}$. A twostep real time PCR was conducted on a 96 well plate using the iCycler program (Bio-Rad) and all reactions were run in triplicate. The iCycler program was also used to determine the $\mathrm{Ct}$ number of each reaction. Ct numbers from the actin reactions were used to standardize the Ct numbers for DWV from the same samples. Melt curves obtained at the end of the amplification confirmed that each primer pair produced a single amplicon with a single $\mathrm{Tm}$. To produce a standard curve, the $100 \mathrm{bp}$ DWV amplicon was ligated into the pCR2.1 vector using a TA cloning kit (Invitrogen) and the identity of the insert confirmed by DNA sequencing. The resulting plasmid was purified from bacterial cells, quantified, and diluted from $10^{2}$ to $10^{10}$ copies/reaction. The standard curve reactions were run in the identical manner as the unknown samples and on the same plate. The standard curve relating Ct number to copy number was linear from $10^{3}$ to $10^{10}$ copies per reaction $\left(R^{2}=0.99\right)$ and was used to calculate the number of viral RNA molecules per microgram of total bee RNA.

\section{In-Situ Hybridization \\ Production of Probe}

Either the pDWV-F or pDWV-R plasmid DNA was digested with HindIII and phenol/chloroform extracted then ethanol precipitated. One $\mu \mathrm{g}$ of linear plasmid DNA was added to the Digoxiginen Labeling Mix (Roche) in- 
vitro transcription reaction with the T7 RNA polymerase according to manufacturer's instructions. The resulting single-stranded riboprobes of approximately $400 \mathrm{nt}$ were then quantified according to the dot blot method.

\section{Preparation of Bee Brains}

Bee brains were dissected in DEPC treated bee saline solution and then placed in $4 \%$ paraformaldehyde $/ 1 \times$ PBS for 2 hours. The brains were incubated in $18 \%$ sucrose $/ 1 \times$ PBS overnight at $4^{\circ} \mathrm{C}$ before being embedded into the OCT embedding medium. The embedded brains were cryosectioned at $10 \mu \mathrm{m}$, and mounted on FisherPlus slides. The sections were then dried overnight at $27^{\circ} \mathrm{C}$ and stored at $-20^{\circ} \mathrm{C}$ until the in-situ hybridization was carried out.

\section{Hybridization/Detection}

The sections were fixed in 4\% paraformaldehyde for 15 mins at room temperature. Sections were incubated with $10 \mathrm{mg} / \mathrm{ml}$ Proteinase K in $10 \mathrm{mM}$ Tris- $\mathrm{HCl}, \mathrm{pH}$ 8.0, $1 \mathrm{mM}$ EDTA. Then sections were fixed again in $4 \%$ paraformaldehyde for 10 mins and then rinsed in $1 \times$ PBS. Finally sections were dehydrated in increasing concentrations of ethanol $(70 \%, 80 \%, 95 \%, 100 \%)$. Sections were then hybridized to the sense or antisense digoxigenin-labled riboprobes $(1000 \mathrm{ng} / \mathrm{ml})$ in a solution of $50 \%$ formamide, 10 mM Tris-HCl, pH 7.6, 200 mg/ml tRNA, $1 \times$ Denhart's solution, $10 \%$ dextran sulfate, $600 \mathrm{mM} \mathrm{NaCl}$, $0.25 \%$ SDS, $1 \mathrm{mM}$ EDTA overnight at $50^{\circ} \mathrm{C}$. The sections were then washed in the following buffers at $50^{\circ} \mathrm{C}(0.2 \times$ SSC, $2 \times$ SSC, $2 \times$ SSC $/ 50 \%$ formamide, $5 \times$ SSC). Digoxigenin-labeled probes were detected with a sheep anti-digoxigenin-alkaline phosphatase antibody according to manufacturer's instructions (Roche). Color development was done with NBT/BCIP in a buffer containing lavimisole $(1 \mu \mathrm{M})$. Sections without any probe were used as negative controls. The sections were left in the NBT/BCIP solution for about 2 hours or until optimum staining was reached. To stop the staining, sections were incubated in $10 \mathrm{mM}$ Tris- $\mathrm{HCl}, 1 \mathrm{mM}$ EDTA for 10 minutes, and were rinsed briefly in ultra pure water. A coverslip was mounted on the sample using the permanent mounting agent Fluormount G. The pictures of the staining were captured using a Nikon E800 microscope and a Hamamatsu digital camera using the Simple PCI software. Adjustments of brightness and contrast of each image was done using Photoshop.

\section{Competing interests}

The authors declare that they have no competing interests.

\section{Authors' contributions}

MCP was responsible for producing the DWV plasmids, developing the experimental design and protocols, and assisting with data interpretation. ECE was responsible for collecting and dissecting the bee brains and assisting with data interpretation. KSS was responsible for carrying out the real-time PCR and in-situ hybridizations and researching the background information. All authors contributed to writing and editing the manuscript.

\section{Acknowledgements}

Preliminary studies of DWV were completed by Courtney Hill and Nathaniel Piel. We thank Dr. Joe Moore for his help with the histological preparations. Chen Mao assisted with the molecular methods. We would also like to thank Dr. Diana Cox-Foster, Department of Entomology at Penn State University, for providing a DWV positive beehive and Mr. Craig Cella for doing the same. MCP and ECE were funded by a grant from the Pennsylvania Department of Agriculture, a Scholarly Development Grant, and the Department of Biology at Bucknell University, and KSS was supported by the Kalman Undergraduate Research Fund at Bucknell University.

\section{References}

I. Kremen C, Williams NM, Thorp RW: Crop pollination from native bees at risk from agricultural intensification. Proc Natl Acad Sci USA 2002, 99:16812-16816.

2. Sabbahi R, De Oliveira D, Marceau J: Influence of honey bee (Hymenoptera: Apidae) density on the production of canola (Crucifera: Brassicacae). J Econ Entomol 2005, 98:367-372.

3. Sabara HA, Winston ML: Managing honey bees (Hymenoptera: Apidae) for greenhouse tomato pollination. I Econ Entomol 2003, 96:547-554.

4. Chittka L, Thomson JD, Waser NM: Flower constancy, insect psychology, and plant evolution. Naturwissenschaften 1999, 86:36I-377.

5. Allen M, Ball B: The incidence and world distribution of honey bee viruses. Bee World 1996, 77:141-162.

6. Lanzi G, de Miranda JR, Boniotti MB, Cameron CE, Lavazza A, Capucci L, Camazine SM, Rossi C: Molecular and biological characterization of deformed wing virus of honeybees (Apis mellifera $L$.). J Virol 2006, 80:4998-5009.

7. Baker AC, Schroeder DC: The use of RNA-dependent RNA polymerase for the taxonomic assignment of Picorna-like viruses (order Picrornavirales) infecting Apis mellifera L. populations. Virol J 2008, 5: 10 .

8. Calderon R, van Veen J, Arce H, Esquivel M: Presence of deformed wing virus and Kashmir bee virus in Africanized honey bee colonies in Costa Rica infested with Varroa destructor. Bee World 2003, 84: II2-II6.

9. Berenyi O, Bakonyi T, Derakhshifar I, Koglberger H, Topolska G, Ritter W: Phylogenetic analysis of deformed wing virus genotypes from diverse geographic origins indicate recent global distribution of the virus. Appl Environ Microbiol 2007, 73:3605-36II.

10. Bailey L, Ball B: Honey Bee Pathology London: Academic Press; I99I.

II. Morse R, Flottum K: Honey Bee Pests, Predators, and Diseases Boston: Root, A. I. Company; 1997.

12. Bowen-Walker PL, Martin SJ, Gunn A: The transmission of deformed wing virus between honeybees (Apis mellifera $L$.) by the ectoparasitic mite varroa jacobsoni Oud. I Invertebr Pathol 1999, 73:101-106.

13. Nordström S: Distribution of deformed wing virus within honey bee (Apis mellifera) brood cells infested with the ectoparasitic mite Varroa destructor. Exp Appl Acarol 2003, 29:293-302

14. Navajas M, Migeon A, Alaux C, Martin-Magniette M, Robinson G, Evans J, Cros-Arteil S, Crauser D, Le Conte Y: Differential gene expression of the honey bee Apis mellifera associated with Varroa destructor infection. BMC Genomics 2008, 9:30I.

15. Yang X, Cox-Foster D: Impact of an ectoparasite on the immunity and pathology of an invertebrate: Evidence for host immunosuppression and viral amplification. Proc Natl Acad Sci USA 2005, I02:7470-7475.

16. De Miranda JR, Fries I: Venereal and vertical transmission of deformed wing virus in honeybees (Apis mellifera L.). J Invertebr Pathol 2008, 98: I84-189. 
17. Yue C, Schröder M, Gisder S, Genersch E: Vertical-transmission routes for deformed wing virus of honeybees (Apis mellifera). J Gen Virol 2007, 88:2329-2336.

18. Chen YP, Pettis JS, Collins A, Feldlaufer MF: Prevalence and transmission of honeybee viruses. Appl Environ Microbiol 2006, 72:606-6II.

19. Berenyi O, Bakonyi T, Derakhshifar I, Kögelberger H, Nowotny $\mathrm{N}$ : Occurrence of six honeybee viruses in diseased Austrian apiaries. Appl Environ Microbiol 2006, 72:24I4-2420.

20. Norstrom S, Fries I, Aarhus A, Hansen H, Korpela S: Virus infection in Nordic honeybee colonies with no, low or severe Varroa jacobsoni infestations. Apidologie 1999, 30:475-484.

21. Tentcheva D, Gauthier L, Zappulla N, Dainat B, Cousserans F, Colin $M E$, Bergoin M: Prevalence and seasonal variations of six bee viruses in Apis mellifera L. and Varroa destructor mite populations in France. Appl Environ Microbiol 2004, 86:7 I85-7I9I.

22. Ongus JR, Roode EC, Pleij CWA, Vlak JM, van Oers MM: The 5' nontranslated region of Varroa destructor virus I (genus Iflavirus): structure prediction and IRES activity in Lymantria dispar cells. J Gen Virol 2006, 87:3397-3407.

23. Fujiyuki T, Takeuchi H, Ono M, Ohka S, Sasaki T, Nomoto A, Kubo $T$ : Novel insect picorna-like virus identified in the brains of aggressive worker honeybees. I Virol 2004, 78: 1093-I I00.

24. Fujiyuki T, Ohka S, Takeuchi H, Ono M, Nomoto A, Kubo T: Prevalence and phylogeny of Kakugo virus, a novel insect picornalike virus that infects the honeybee (Apis mellifera L.), under various colony conditions. J Virol 2006, 80: II528-II538.

25. Rortais A, Tentcheva D, Papachristoforou A, Gauthier L, Arnold G, Colin M, Bergoin M: Deformed wing virus is not related to honey bees' aggressiveness. Virol J 2006, 3:6I.

26. Yue C, Genersch E: RT-PCR analysis of deformed wing virus (DWV) in honey bees (Apis meillifera) and mites (Varroa destructor). J Gen Virol 2005, 86:3419-3424.

27. Iqbal $J$, Mueller $U$ : Virus infection causes specific learning deficits in honeybee foragers. Proc Biol Sci 2007, 274:15I7-I52।.

28. Verheyden B, Lauwers S, Rombaut R: Quantitative RT-PCR ELISA to determine the amount and ratio of positive- and negative strand viral RNA synthesis and the effect of guanidine in poliovirus infected cells. J Pharm Biomed Anal 2003 33:303-308

29. Caliguiri LA, Tamm I: The Role of cytoplasmic membranes in poliovirus biosynthesis. Virology 1970, 42:100-III.

30. Johnson RM, Evans JD, Robinsone GE, Berenbaum MR: Changes in transcript abundance relating to colony collapse disorder in honey bees (Apis mellifera). Proc Natl Acad Sci USA 2009, 106: 14790-14795.

31. Cox-Foster DL, Conlan S, Holmes EC, Palacios G, Evans JD, Moran NA, Quan PL, Briese T, Hornig M, Geiser DM, Martinson V, vanEngelsdorp D, Kalkstein AL, Drysdale A, Hui J, Zhai J, Cui L, Hutchison SK, Simons JF, Egholm M, Pettis JS, Lipkin WI: A metagenomic survey of microbes in honey bee colony collapse disorder. Science 2007, 3 1 8:283-287.

32. Fievet J, Tentcheva D, Gauthier L, de Miranda J, Cousserans F, Colin ME, Gergoin M: Localization of deformed wing virus infection in queen and drone Apis mellifera L. Virol J 2006, 3:16.
Publish with Bio Med Central and every scientist can read your work free of charge

"BioMed Central will be the most significant development for disseminating the results of biomedical research in our lifetime. "

Sir Paul Nurse, Cancer Research UK

Your research papers will be:

- available free of charge to the entire biomedical community

- peer reviewed and published immediately upon acceptance

- cited in PubMed and archived on PubMed Central

- yours - you keep the copyright

Submit your manuscript here:

http://www.biomedcentral.com/info/publishing_adv.asp
BioMedcentral 